\title{
The Phenomenon of Underemployment in Poland
}

\begin{abstract}
The labour market is usually associated with phenomena such as unemployment, employment and professional activity/inactivity. The ways in which these categories are shaped depend on various factors of an economic, social and technological nature. It is impossible to disagree with the statement that the contemporary labour market - local, national, and global - is undergoing dynamic changes. In the public debate, the themes of flexicurity, flexible forms of employment, reconciling professional work with private life, and lifelong learning appear more frequently. They cause heated discussions and often also controversies, since their impact on the situation of workers and employers in the labour market is increasing. Observing the trends in the world economy and the global labour market, it can be argued that employment becomes a privilege.

Due to the reasons mentioned above, in the paper, issues which relate to 'incomplete' employment are discussed. Theoretical considerations are focused on the terminological and methodological problems related to the interpretation of the concept of underemployment both in the Polish and foreign literature. Furthermore, the relationships between the phenomenon of underemployment and the concept of employment flexibility and security are presented, since they are extremely important from the perspective of the contemporary labour market. The theoretical analysis is complemented by a statistical analysis of empirical data that illustrates the current scale of the phenomenon of underemployment in the labour market in Poland compared to other European Union member states (EU-28). The article adopts the research thesis that in Poland there is a problem of 'incomplete' employment. Therefore, the aim of this paper is to attempt to identify the scale of this phenomenon on the Polish labour market. Implementation of this objective will be possible thanks to the study of national and foreign literature and a conducted statistical analysis of selected indicators of the labour market in the context of this phenomenon, obtained from the database of the European Statistical Office (Eurostat).
\end{abstract}

Keywords: labour market, underemployment, flexicurity, flexible forms of employment

JEL Classification: A13, M54 


\section{Introduction}

As a result of changes taking place in the Polish and European labour market, there is developing debate about the phenomenon of underemployment, that is 'incomplete' employment. It seems that one of the biggest problems, especially after the recent global economic crisis, ${ }^{1}$ is - next to the high unemployment among people of the less 'privileged' groups, i.e. young people, women, people over 65 years of age and long-term unemployed - the enlarging group of underemployed.

The processes that are currently taking place in the labour market in Poland may generate moderate optimism. The estimations of the Ministry of Labour and Social Policy show that the registered unemployment rate remain at single-digit level - in October 2016 it fell to an exceptionally low level of 8.2\% (compared to October 2015 it fell by 1.4 p.p.). The statements of Elżbieta Rafalska, Minister of Family, Labour and Social Policy in the government of Prime Minister Beata Szydło, confirmed the continuing trend of improvement in the labour market: 'Such low level of unemployment is a clear indication that the actions taken by our government over the last year are showing results. Our goal is to improve the quality of life of Poles, including the sphere of work. ${ }^{2}$ In other words, the lowest level of unemployment over the last seven years was reported in 2016, which is an undoubted success, taking into account the fact that the Member States of the European Union (EU-28), including Poland, are still struggling with the negative effects of financial and economic crisis.

The first part of the study addresses terminological and methodological issues associated with the concepts of underemployment and underemployed persons. The second part presents the concept of flexicurity, along with flexible forms of employment and organization of working time, which are often connected with the phenomenon of underemployment. In the third and last part of the study, selected labour market indicators are analysed in the context of the phenomenon underemployment in Poland on the background of the EU-28. The adopted research thesis is that in Poland there is a problem of 'incomplete' employment. Therefore, the aim of this paper is to attempt to identify the scale of this phenomenon on the Polish labour market. Achieving this objective will be possible due to the study of domestic and foreign literature and conducted statistical analysis of selected indicators of the labour market in the context of this phenomenon, obtained from the database of the European Statistical Office (Eurostat).

\footnotetext{
${ }^{1}$ More details about the impact of the global economic crisis on the Polish and European labor market in: K. Cymbranowicz, Wplyw kryzysu gospodarczego na politykę rynku pracy i zatrudnienia w państwach członkowskich Unii Europejskiej [in:] Kryzys Unii czy kryzys w Unii? Kierunki dyskusji nad przyszłościa integracji europejskiej, ed. H. Tendera-Właszczuk, Difin, Warsaw 2014, p. 189--242.

${ }^{2}$ Own translation based on the website of Ministry of Family, Labour and Social Policy, http://www. mpips.gov.pl/aktualnosci-wszystkie/zatrudnienie-i-przeciwdzialanie-bezrobociu/art,8359,w-pazdzierni ku-bezrobocie-spadlo-do-8-2.html (accessed: Novermber 15, 2016).
} 


\section{The essence of the phenomenon of underemployment: terminological and methodological issues}

To answer the question concerning the essence of the phenomenon of underemployment on the modern labour market, it is essential to determine, what it is.

Among the researchers and theorists of social and economic life, the concept is defined ambiguously. In Polish literature, it has no single, commonly used equivalent of the English version. This leads to a situation in which this term is interpreted differently. Depending on the adopted perspective the phenomenon of underemployment is usually translated as 'incomplete' or 'inadequate' employment. ${ }^{3}$ It is assumed that one of the characteristics of the phenomenon of underemployment is a failure to comply with generally accepted and applicable to employment standards, such as: hiring and keeping the necessary number of employees with specific qualifications, estimating the qualification requirements and possibilities of their fulfilment, improving the efficiency of the labour force.

According to the Organization for Economic Cooperation and Development (OECD), the term underemployment is related to persons who are employed below their qualifications. In turn International Labour Organization (ILO), by the concept of 'incomplete' or 'inadequate' employment understands situations in which: ${ }^{4}$

(1) work time is shorter than preferred by the employee, as he or she is ready and able to work full-time,

(2) the work is not very productive, because employee receives low wages or works below their qualifications.

Both organizations distinguish two forms of such employment: ${ }^{5}$

(1) visible underemployment includes people who work part-time, although nothing stands in their way to work full-time,

(2) invisible underemployment includes people who work in their profession, but their skills are not properly used.

With reference to the above, it is worth noting that in the recommendations for methods of measuring the underemployment ${ }^{6}$ the International Labour Organization proposes to take into account not only the level of employment, but also the efficiency of the labour force, ${ }^{7}$ which will allow to conduct more comprehensive analysis ${ }^{8}$.

\footnotetext{
${ }^{3}$ A. Kiersztyn, Underemployment: Nowe zjawisko czy nowy termin?, „Polityka Społeczna” 2007, No. 10, p. 18.

${ }^{4}$ ILO, Report I: Underemployment, $16^{\text {th }}$ International Conference of Labor Statisticians, Geneva 1998, p. $10-13$.

${ }^{5}$ Ibidem, p. 13-25.

${ }^{6}$ The definition of the indicator 'incomplete' employment for economic reasons was adopted by the $13^{\text {th }}$ International Conference of Labour Statisticians (ICLS) in 1982. According to the essence of this definition, underemployment includes persons who even though they worked or had a job during the reference week, they were willing and available to work 'better' or 'more adequately.'

${ }^{7}$ The International Labour Organization since its beginning indicates the need to develop common methods for measuring different phenomena associated with the labour market for the international comparisons. These standards are set by the International Conference of Labour Statisticians.

${ }^{8}$ ILO, op. cit., p. 36.
} 


\section{The phenomenon of underemployment and the concept of flexibility and security on the labour market}

The phenomenon of the 'incomplete' employment is often connected with the concept of flexicurity and flexible forms of employment and organization of working time. The sense of the concept of flexicurity ${ }^{9}$ is to try to simultaneously combine flexibility and security in the labour market. In other words, it is the facilitated process of hiring and firing workers by the employer, but at the same time ensuring the high level of social security for the employee ${ }^{10}$.

Keeping this policy is possible only because of the co-existence and mutual complementarity of the four pillars of labour market, the so-called flexicurity components, which include: ${ }^{11}$

(1) contractual arrangements, achieved through modern labour laws, collective agreements and work organization,

(2) active labour market policies, which helps employees to more easily adapt to changes in the market, simplify job changing and help those inactive for various reasons to acquire the ability to work,

(3) lifelong learning, providing a constant ability of workers to adapt to changes on the market and to be employed,

(4) modern social security systems that provide adequate financial security to people in the difficult income situation, which on the one hand favours the professional reactivation, on the other - enables reconciling professional career with the obligations related to private life.

Due to the fact that the issue of 'incomplete' employment is usually connected with the first of the four components of flexicurity featured above, i.e. predictable and flexible forms of employment and organization of working time, it will be further discussed. The term predictable and flexible forms of employment and organization of working time must be understood as a broad catalogue of non-standard forms of employment, corresponding to the needs of the modern labour market. In the literature, it can be observed that there is a distinction between flexible forms of employment and flexible forms of organization of working time, although this is an ambiguous division. Flexible forms of employment include: fixed-term and other temporary employment contracts, part-time employment, mini-jobs, on-call work and job sharing, home working and telework, flexible forms of working time, training and apprenticeship contracts, occasional work contracts, civil law contracts. ${ }^{12}$

\footnotetext{
${ }^{9}$ More details about the concept of flexicurity in: K. Cymbranowicz, Flexicurity - A New Tool offor Human Recourses Management [in:] Knowledge-Economy-Society. Contemporary Tools of Organizational Resources Management, eds. P. Lula, T. Rojek, Cracow University of Economics, Cracow 2014, p. $203-212$.

${ }^{10}$ Support for the dismissed worker must be large enough to guarantee him adequate financial security in a period without employment, that would allow him to find a new job.

${ }^{11}$ European Commission, Towards Common Principles of Flexicurity. More and better jobs through flexibility and security, Brussels 2007, $\operatorname{COM(2007)} 359$ final, p. 6.

${ }^{12}$ Own translation based on: C. Sadowska-Snarska, Elastyczne formy pracy jako instrument ułatwiajacy godzenie życia zawodowego z rodzinnym, Wydawnictwo Wyższej Szkoły Ekonomicznej w Białymstoku, Białystok 2006, p. 23-32.
} 
Among the flexible forms of organization of working time there are distinguished: task-oriented work schedule, equivalent working time, interrupted work time, flexible working hours, variable hours of starting work, individual work schedule, the shortened work week system, working in the weekend system, reduction of working time instead of using parental leave, individual working time accounts. ${ }^{13}$ The experience connected with the increasing use of available flexible solutions on the labour market indicate that while using the atypical forms of employment, we can meet both the positive and negative effects of such solutions. ${ }^{14}$ Among the benefits, the most distinguished are, among others: better chances of finding a suitable job, better conditions for reconciling work and private life, better career opportunities, greater motivation to work, eliminating the stress associated with the need to use ad hoc solutions, reducing the risk of losing their jobs. Among the costs however there are: lack of separation between work and free time, restricted contact with the work environment, limited access to information, training, promotion, employee benefits and reduced job security. Each flexible solution generates appropriate positive and negative effects. Due to the many variants of flexible forms of employment and organization of working time, it is not possible to indicate all of the positive or negative sides of each of the possible solutions.

The concept of flexicurity has its advantages and disadvantages. On the one hand, thanks to flexible forms of employment, the least 'privileged' social groups on the labour market, i.e. young people, women, people over the age of 65 and the long-term unemployed, can still be professionally active. On the other hand, it should be kept in mind that flexible forms of work often replace traditional employment relation, which entails a number of consequences for both the employee and the employer, in particular - lowering the quality of employment, which is the beginning of the problem that is underemployment.

\section{Analysis of selected labour market indicators describing the scale of the phenomenon of underemployment in Poland against the background of the EU-28}

In 2004, CBOS (pl. Centrum Badania Opinii Społecznej, ang. Public Opinion Research Centre), conducted a study dealing with the importance of work in the life of Polish society. ${ }^{15}$ The results showed that among the values recognized by Poles as the most important in everyday life professional work plays an important role. Having a job, a stable employment was in fact in fourth place among the most important values in life that give it a sense (right after successful family life, health and values such as love and friendship). Responding to a question why Poles appreciate work,

\footnotetext{
${ }^{13}$ Own translation based on: C. Sadowska-Snarska, Szkolenia pracowników z zakresu elastycznych form pracy. Poradnik dla instytucji szkoleniowych, Wydawnictwo Wyższej Szkoły Ekonomicznej w Białymstoku, Białystok 2007, p. 36-42.

${ }^{14}$ Ibidem, p. 77-82.

${ }^{15}$ The study 'Current problems and events' (167) was conducted on April 2-5, 2004 on representative random sample of 993 adult Poles.
} 
almost three-quarters of the respondents were of the opinion that the work gives meaning to life. From this it follows that the vast majority of Poles believe that work is an autotelic value - they do not treat her instrumentally, as a necessary condition of existence, or as a way of getting rich and realize the dream of material nature (see: Figure 1).

Figure 1. The value of professional work in the lives of Poles (in \%)

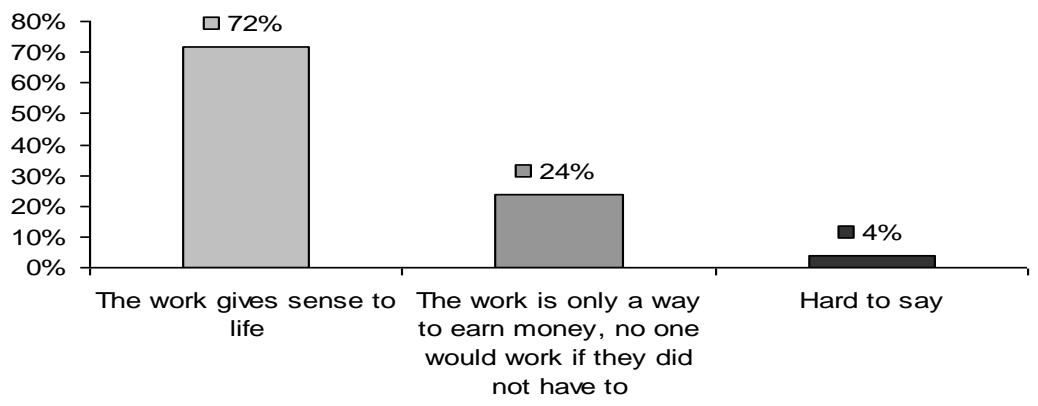

Source: CBOS, Praca jako wartość, Komunikat z badań, Warsaw 2004, p. 2.

In the CBOS' studies, on the first place among the defining characteristics of good jobs, the respondents mention high wages and steady employment, although it should be emphasized that the views are diverse in age, sex and education of the respondents (see: figure 2).

The results of these studies are interesting because of the phenomenon of underemployment discussed here, since it would be difficult to connect them with any of the listed characteristics of work which is considered as good.

Undertaking the analysis of the economic conditions of underemployment, the main variables describing this phenomenon should be indicated. The following tables and figures show the relative proportion of part-time workers in labour markets of the EU Member States. The data used for these analyses comes from Eurostat's European Labor Force Survey Database.

In 2014, among the 44.1 million persons working part-time in EU-28, the vast majority were women (32.7 million). Almost 10.3 million were underemployed, meaning they wished to work more hours and were available to do so. ${ }^{16}$ The majority of them were persons aged 25-54 years (7.4 million). The information published by Eurostat states that this corresponds to $23.4 \%$ of all part-time workers and $4.7 \%$ of total employment in the EU-28.

\footnotetext{
16 'An underemployed part-time worker is a person aged 15-74 working part-time who would like to work additional hours and is available to do so. Part-time work is recorded as self-reported by individuals. This statistical indicator covers persons who, in spite of being employed, do not work full-time and lack a sufficient volume of work, which is somewhat similar to being unemployed. The part-time requirement in the definition is important because the people who work full-time and still want to work more hours have a different profile: in spite of working many hours they have insufficient income; underemployed part-time, on the other hand, highlights situations of insufficient volume of work and underutilized labour among persons already employed'. Source: the website of Eurostat, http://ec.europa.eu/eurostat/statistics-explained/index.php/Glossary:Underemployed_part-time_worker (accessed: March 10, 2016).
} 
Figure 2. Desirable work characteristics according to Poles (in \%)

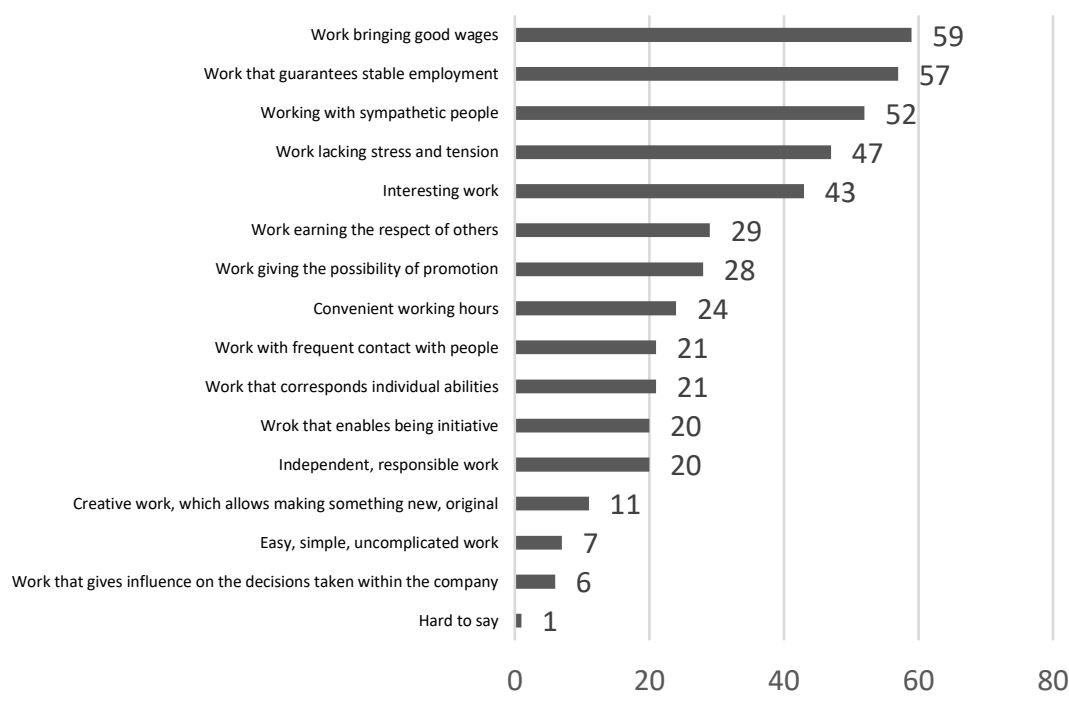

Note: The respondents could choose maximum five characteristics

Source: CBOS, op. cit., p. 6.

Alongside the economically active population, ${ }^{17} 11.8$ million economically inactive persons aged 15 to 74 in the EU-28 had in 2014 a certain attachment to the labour market and could be considered as a potential additional labour force. Among them:

(1) 9.6 million that were available to work but were not seeking ${ }^{18}$ had the following age distribution: 2 million were aged 15-24; 5.6 million were aged 25-54; 2 million aged 55-74; there are fewer people in the age group 5574 in all indicators,

\footnotetext{
${ }^{17}$ The economically active persons, also called labour force, are those aged 15-74 either employed or unemployed. Conversely, the economically inactive population gathers people aged 15-74 neither employed nor unemployed.

18 'Persons available to work but not seeking are persons aged 15-74 neither employed nor unemployed who want to work, are available for work in the next 2 weeks but do not seek work. This indicator covers jobless people who do not qualify for recording as unemployed because they are not actively looking for a job. It includes, among others, discouraged jobseekers and persons prevented from job seeking due to personal or family circumstances. The sum of the two groups persons seeking work but not immediately available and persons available to work but not seeking is called the potential additional labour force (PAF). Persons in the PAF are not part of the standard labour force, which is the sum of employed and unemployment persons. However, persons in the PAF have a stronger attachment to the labour market than other economically inactive persons'. Source: the website of Eurostat, http://ec.europa.eu/eurostat/statistics-explained/index.php/Glossary:Person_available_to_work_but_not_seeking (accessed: March 10, 2016).
} 
(2) 2.2 million seeking work but not immediately available ${ }^{19}$ had the following age distribution: 0.7 million were aged $15-24 ; 1.3$ million were aged 25-54; 0.3 million were aged 55-74; therefore, this group were in a large part students seeking a job to start after graduation.

In 2014, the large majority of part-time workers being underemployed in the EU-28 were women (6.8 million). Almost 12 million total potential additional EU28 's labour force were also women (see: figure 3 ).

Figure 3. Part-time underemployed and potential additional labour force by sex in the EU28 in 2014 (in \%)

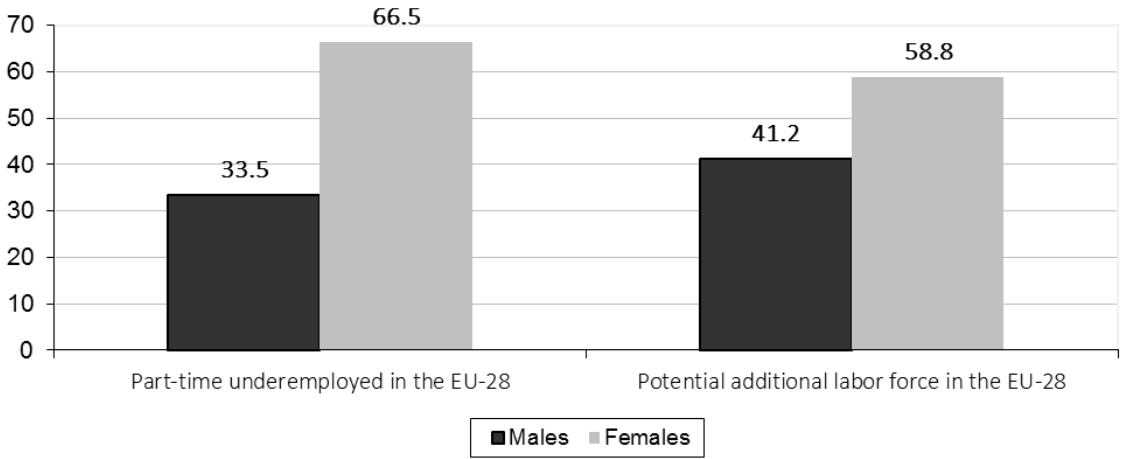

Source: Own compilation based on the Eurostat database: http://ec.europa.eu/eurostat/statisticsexplained/index.php/Underemployment_and_potential_additional_labour_force_statistics (accessed: March 10, 2016).

In 2014, the proportion of underemployed part-time workers among total parttime workers varied significantly across the EU-28. Situation in Poland was quite good. Firstly, $31.2 \%$ of all part-time employed were persons aged 15 to 74 working part-time and being underemployed (i.e. above the EU-28 average of 9 p.p.). Secondly, 2.4\% of all employees were persons who were aged 15 to 74 working parttime and being underemployed (i.e. below the EU-28 average of 2.1 p.p.). A majority of part-time workers wished to work more while being available to do so e.g. in Greece, Cyprus and Spain. At the opposite end of the scale, the Netherlands registered by far the smallest share of underemployed part-time workers, followed by Luxembourg, Denmark, Estonia and the Czech Republic (see: table 1).

\footnotetext{
19 'Persons seeking work but not immediately available are the sum of persons aged 15-74 neither employed nor unemployed who: are actively seeking work during the last 4 weeks but not available for work in the next 2 weeks; found a job to start in less than three months and are not available for work in the next 2 weeks; found a job to start in three months or more; are passively seeking work during the last 4 weeks and are available for work in the next 2 weeks. Passive job search is e.g. waiting the results of a job interview. The first of those 4 groups is the biggest by far. The three latter groups are included in this indicator for completeness as they are not ILO unemployed but have many common characteristics with people in the first group. This indicator describes jobless people who do not qualify for recording as unemployed because of their limited availability to start a new job'. Source: the website of Eurostat, http://ec.europa.eu/eurostat/statistics-explained/index.php/Glossary:Person_seeking_work_but_not_im mediately_available (accessed: March 10, 2016).
} 
THE PHENOMENON OF UNDEREMPLOYMENT...

Table 1. Underemployment and part-time work in the EU-28 in 2014

\begin{tabular}{|c|c|c|c|c|c|}
\hline \multirow[b]{2}{*}{ Category } & \multicolumn{4}{|c|}{$\begin{array}{l}\text { Persons aged } 15 \text { to } 74 \text { working part-time } \\
\text { and being underemployed }\end{array}$} & \multirow{2}{*}{$\begin{array}{c}\text { Part-time } \\
\text { employed } \\
\text { aged } 15 \text { to } 74, \\
\text { in } \% \text { of total em- } \\
\text { ployment }\end{array}$} \\
\hline & $\begin{array}{c}\text { In } \\
\text { thousands }\end{array}$ & $\begin{array}{c}\text { Share of } \\
\text { women } \\
(\%)\end{array}$ & $\begin{array}{l}\text { As } \% \text { of } \\
\text { part-time } \\
\text { employed }\end{array}$ & $\begin{array}{l}\text { As \% of } \\
\text { total em- } \\
\text { ployment }\end{array}$ & \\
\hline Belgium & 154 & 72 & 14.2 & 3.4 & 24.0 \\
\hline Bulgaria & 34 & 53 & 43.5 & 1.1 & 2.6 \\
\hline Czech Republic & 35 & 71 & 11.4 & 0.7 & 6.2 \\
\hline Denmark* & 74 & 63 & 10.7 & 2.7 & 25.5 \\
\hline Germany & 1626 & 73 & 14.9 & 4.1 & 27.5 \\
\hline Estonia & 7 & 55 & 11.2 & 1.1 & 9.6 \\
\hline Ireland & 128 & 54 & 28.7 & 6.7 & 23.4 \\
\hline Greece & 239 & 55 & 72.1 & 6.8 & 9.4 \\
\hline Spain & 1576 & 69 & 57.3 & 9.1 & 15.9 \\
\hline France** & 1561 & 74 & 32.1 & 6.1 & 18.9 \\
\hline Croatia & 34 & 59 & 36.6 & 2.2 & 6.0 \\
\hline Italy & 742 & 61 & 18.3 & 3.3 & 18.3 \\
\hline Cyprus & 34 & 57 & 65.9 & 9.3 & 14.0 \\
\hline Latvia & 27 & 62 & 40.5 & 3.0 & 7.4 \\
\hline Lithuania & 31 & 60 & 26.1 & 2.4 & 9.0 \\
\hline Luxembourg & 5 & 77 & 10.5 & 2.0 & 18.8 \\
\hline Hungary & 80 & 55 & 30.6 & 2.0 & 6.4 \\
\hline Malta & 5 & 61 & 15.5 & 2.5 & 16.4 \\
\hline Netherlands & 169 & 63 & 4.0 & 2.0 & 50.5 \\
\hline Austria & 169 & 74 & 14.9 & 4.1 & 27.7 \\
\hline POLAND & 377 & 63 & 31.2 & 2.4 & 7.6 \\
\hline Portugal & 245 & 61 & 45.8 & 5.5 & 12.1 \\
\hline Romania & 238 & 34 & 27.7 & 2.8 & 10.0 \\
\hline Slovenia & 26 & 60 & 26.2 & 2.8 & 10.8 \\
\hline Slovakia & 47 & 47 & 37.8 & 2.0 & 5.2 \\
\hline Finland & 90 & 64 & 23.9 & 3.7 & 15.4 \\
\hline Sweden & 238 & 66 & 19.1 & 5.0 & 26.1 \\
\hline United Kingdom & 1813 & 64 & 22.4 & 5.9 & 26.5 \\
\hline EU-28 & 9803 & 67 & 22.2 & 4.5 & 20.3 \\
\hline
\end{tabular}

Notes: * Due to methodological issues, the categories 'underemployed,' 'persons seeking work' and 'persons available to work' for Denmark should be considered as 'uncertain.'

** Data for France exclude the overseas departments.

Source: Own compilation based on the Eurostat database: http://ec.europa.eu/eurostat/statisticsexplained/index.php/Underemployment_and_potential_additional_labour_force_statistics (accessed: March 10, 2016). 
Over the past six years, the share of people working in part-time work and underemployed among employees in total in Poland increased from $1.6 \%$ to $2.4 \%$. It is, however, a slight increase compared to the EU average - an increase from the size of $1.2 \%$ to $4.7 \%{ }^{20}$ (see: table 1 , figure 4 ).

Figure 4. Persons aged 15 to 74 working part-time and being underemployed as $\%$ of total employment in the EU-28 in 2014 (in \%)

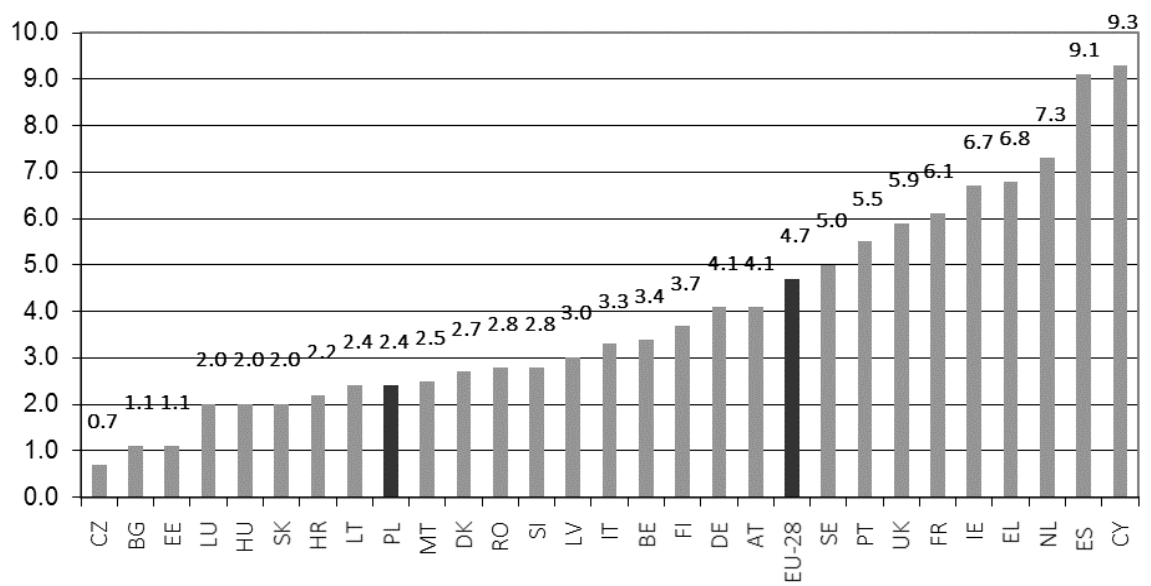

Source: Own compilation based on the Eurostat database: http://ec.europa.eu/eurostat/statisticsexplained/index.php/Underemployment_and_potential_additional_labour_force_statistics (accessed: March 10, 2016).

On the other hand, comparing only the percentage of people employed parttime (total for men and women) among all employees over last six years in the EU28 , it turns out that the percentage increased from $18.1 \%$ in 2008 to $20.3 \%$ in 2014 . The highest percentage of people employed in part-time employment was recorded in the countries of the so-called 'Old fifteen' (EU-15), i.e. the Netherlands (50.3\% in 2014), then respectively in Austria, Germany, UK, Sweden and Denmark - in each of these countries more than one fourth of the employed had part-time work (from $25.5 \%$ to $27.7 \%$ ). This way of employment has not won popularity in the countries of Central and Eastern Europe that joined the Union after 2004, that is Bulgaria, Slovakia, Croatia, the Czech Republic and Hungary. ${ }^{21}$ Poland, with the result of $7.6 \%$, is counted among the latter of the aforementioned groups of countries (see: table 1 and figure 5).

20 Based on the data from Eurostat database: http://ec.europa.eu/eurostat/statistics-explained/index.php/Underemployment_and_potential_additional_labour_force_statistics (accessed: March 10, 2016).

${ }^{21}$ Based on the data from Eurostat database: http://ec.europa.eu/eurostat/statistics-explained/index.php/Underemployment_and_potential_additional_labour_force_statistics (accessed: March 10, 2016). 
Figure 5. Persons aged 15 to 74 working part-time in \% of total employment in the EU-28 in 2014 (in \%)

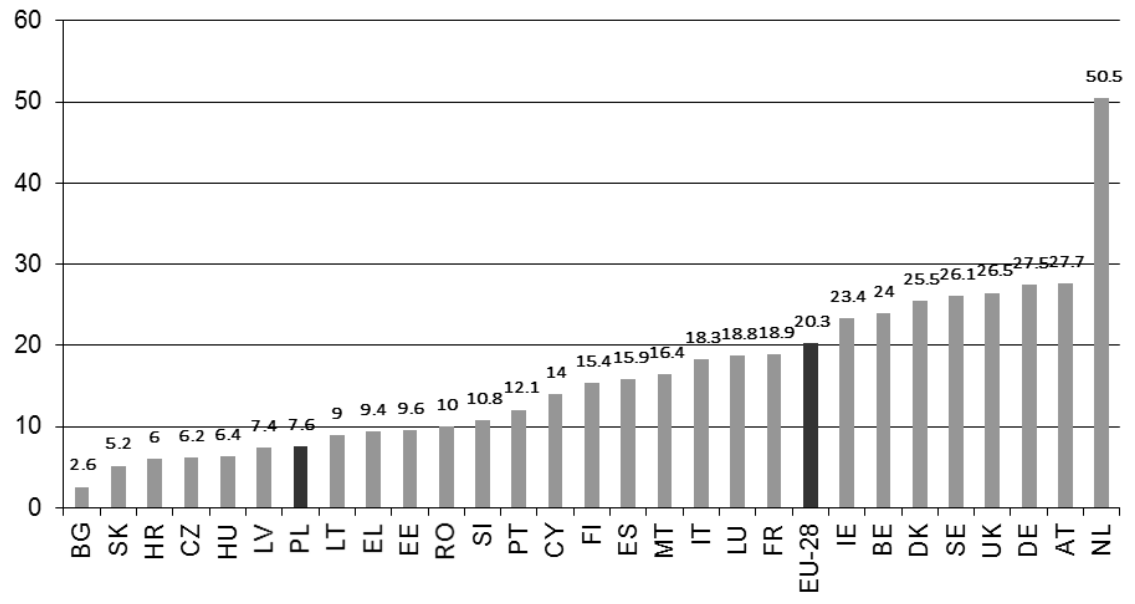

Source: Own compilation based on the Eurostat database: http://ec.europa.eu/eurostat/statisticsexplained/index.php/Underemployment_and_potential_additional_labour_force_statistics (accessed: March 10, 2016).

The figure 6 summarizes the various data concerning people of working age, employed part-time and/or underemployed gender. They represent the situation in the EU-28 in 2014. On this basis, it can be stated that more often the problem of underemployment affects women.

Figure 6. Selected indicators of underemployment and part-time work by sex in aged 15-74 in EU-28 in 2014 (in \%)

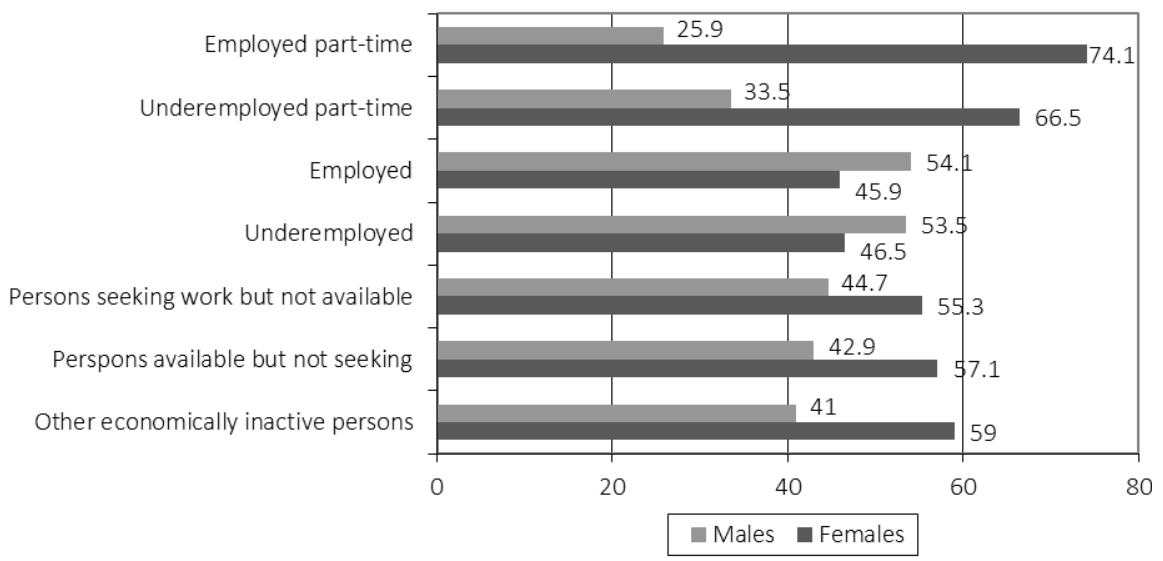

Source: Own compilation based on the Eurostat database: http://ec.europa.eu/eurostat/statisticsexplained/index.php/Underemployment_and_potential_additional_labour_force_statistics (accessed: March 10, 2016). 
Comparing the details for the Member States of the EU-28, it can be stated that in Finland, Great Britain, Sweden, Spain, the share of women employed in parttime work is almost twice as big than that of men. In the Czech Republic, Belgium, Germany, Austria, France and Luxembourg, this difference is almost three times higher (see: figure 7).

Figure 7. Labour market share of males and females as a percentage of persons aged 15 to 74 working part-time and being underemployed in the EU-28 in 2014 (in \%)

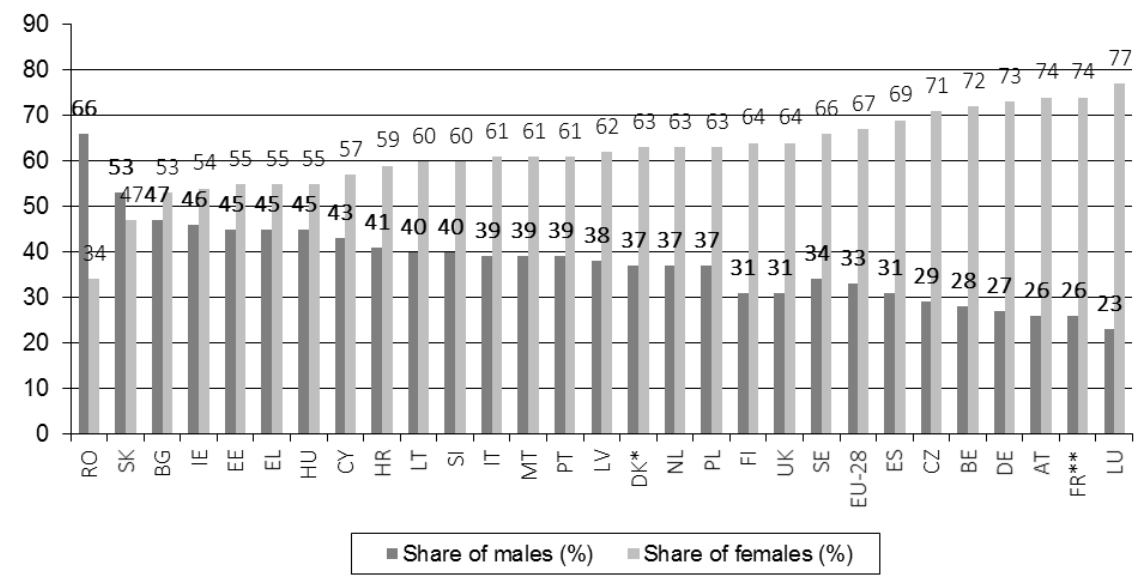
Notes: * Due to methodological issues, the categories 'underemployed', 'persons seeking work' and 'persons available to work' for Denmark should be considered as 'uncertain.' ** Data for France exclude the overseas departments.

Source: Own compilation based on the Eurostat database: http://ec.europa.eu/eurostat/statisticsexplained/index.php/Underemployment_and_potential_additional_labour_force_statistics (accessed: March 10, 2016).

In Poland, these proportions do not differ significantly from the EU average. Moreover, analysing the participation of women and men employed in part-time (as $\%$ of total employees), we can conclude that among both sexes there is no difference in the length of work - in Poland, both women and men work an average of 21.4 hours per week. In other EU Member States the situation is diverse, so in terms of working time, women work a bit longer than men (for the EU-28, the difference is 1.4 hours per week). ${ }^{22}$ Apart from the disputes related with the dilemma of whether part-time work is a sign of preference or discrimination, it can be stated that with the exception of Romania and Slovakia, in all EU Member States, women are more active. On the other hand, analysing the rates of part-time work by gender it can be said that nearly one-third (32.8\%) of working women was employed that way. This is more than three times higher score than for men (9.7\%). In 2014, more than three-

\footnotetext{
${ }^{22}$ Based on the data from Eurostat database: http://ec.europa.eu/eurostat/statistics-explained/index.php/Underemployment_and_potential_additional_labour_force_statistics (accessed: March 10, 2016).
} 
quarters $(76.9 \%)$ of all women employed in the Netherlands worked part-time, which is the highest percentage among all EU Member States. In turn, the least of women were employed under such conditions in Bulgaria (3\%).

Analysing the group of underemployed, it can be said that the phenomenon of underemployment affects mostly young people who are just entering the labour market. Among the analysed age groups, the highest percentage of underemployed occurs in the youngest group, that is between 15 and 24 years. In 2014 in Poland the percentage of young people who faced the problem of underemployment was nearly two times lower than the EU average, which can cause optimism (see: figure 8).

Figure 8 . The underemployment rate in the 15-24 age group, expressed as a percentage of people employed in the EU-28 in 2014 (in \%)

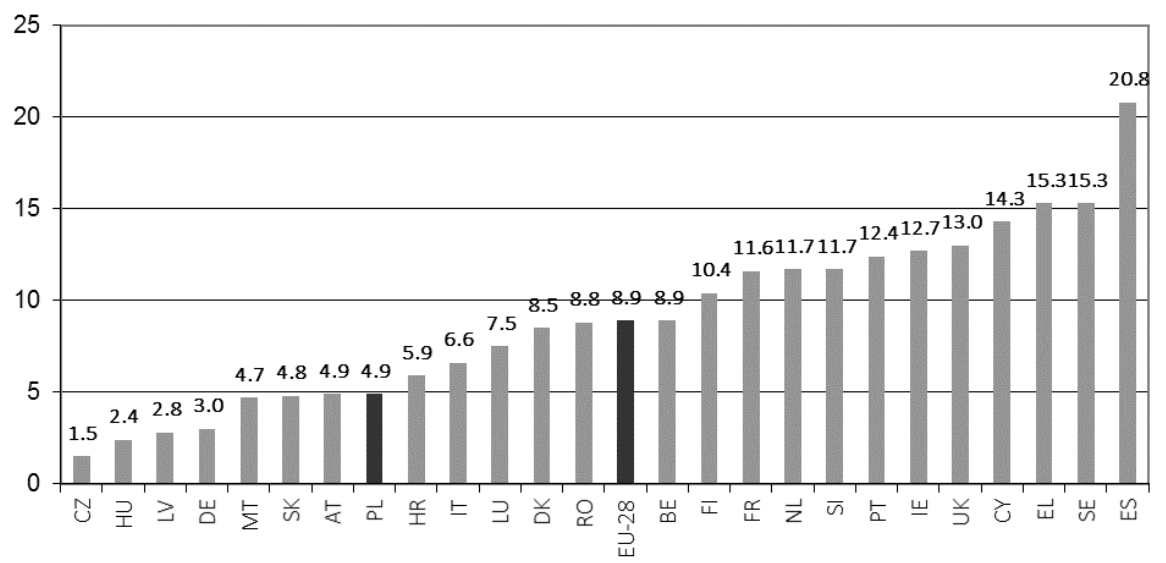

Note: lack of data concerning Bulgaria, Estonia, Lithuania.

Source: Own compilation based on the Eurostat database: http://ec.europa.eu/eurostat/statisticsexplained/index.php/Underemployment_and_potential_additional_labour_force_statistics (accessed: March 10, 2016).

As with the previously analysed underemployment rate for the age group of 15-74 years, divided by gender, expressed as a percentage of employees in 2014, also for the youngest age group, the continuing difference between the higher value of the index among women than men can be observed (in Poland this difference was 3.2 p.p., and in the EU-28 a little bit more -3.7 p.p.).

In summary, the picture that emerges from the above analysis is, in general, that on the Polish labour market:

(1) the number of people working in part-time work and underemployed, who receive low wages for their work or perform work inadequate to professional qualifications is increasing,

(2) problem of underemployment affects women more often than men,

(3) problem of underemployment largely applies to young people that while entering the labour market often undertake work, which is not associated with their qualifications and education. 
Comparing the situation of Poland with other EU Member States, it must be noted that although statistics show that the phenomenon of underemployment exists also on the Polish labour market, its scale is not as large as in Western Europe.

\section{Conclusions}

This paper describes the nature and scale of the phenomenon of underemployment in today's labour market, including focused attention on the situation in Poland and the EU-28.

First, it sought to demonstrate that term is defined ambiguously. In Polish literature, as well as in this paper, the concept is understood as 'incomplete' employment, and the definitions of this group as having an 'incomplete' or 'low' employment.

Secondly, it was pointed out that the phenomenon of underemployment is often associated with the concept of flexicurity and flexible forms of employment and organization of working time, which in recent years have become of greater interest. The basis for these solutions is the assumption that flexibility and employment security are not mutually exclusive, but complementary. The concept of flexicurity can be an effective solution not only theoretically but also practically, in terms of economic and social policies of each Member State of the EU, when its solutions protect the interests of both of employers and employees.

Thirdly, the research confirmed the thesis stated in the introduction, that in Poland there is indeed a problem of 'incomplete' employment, although the scale of this phenomenon is not large, especially when we compare the situation of Poland to other EU Member States. However, this does not mean that we should underestimate the problem and do not attach importance to it. On the contrary, we should constantly monitor the developments on the labour market in Poland and, as far as we can, try to counteract the negative effects, which are inherent to the phenomenon of 'incomplete' employment.

\section{References}

CBOS, Praca jako wartość, Komunikat z badań, Warsaw 2004.

Cymbranowicz K., Flexicurity - A New Tool of for Human Recourses Management [in:] Knowledge-Economy-Society. Contemporary Tools of Organizational Resources Management, eds. P. Lula, T. Rojek, Cracow University of Economics, Cracow 2014.

Cymbranowicz K., Wplyw kryzysu gospodarczego na politykę rynku pracy i zatrudnienia w państwach członkowskich Unii Europejskiej [in:] Kryzys Unii czy kryzys w Unii? Kierunki dyskusji nad przyszłościq integracji europejskiej, ed. H. Tendera-Właszczuk, Difin, Warsaw 2014.

European Commission, Towards Common Principles of Flexicurity. More and better jobs through flexibility and security, Brussels 2007, COM(2007) 359 final. 
ILO, Report I: Underemployment, $16^{\text {th }}$ International Conference of Labor Statisticians, Geneva 1998.

Kiersztyn A., Underemployment: Nowe zjawisko czy nowy termin?, „Polityka Społeczna” 2007, No. 10.

Kryńska E., Flexicurity w Polsce diagnoza i rekomendacje. Raport końcowy z badań, Oficyna Wydawnicza ASPRA-JR, Warsaw 2009.

Kryńska E., Elastyczne formy zatrudnienia i organizacji pracy a popyt na prace $w$ Polsce, Instytut Pracy i Spraw Socjalnych, Warsaw 2003.

Sadowska-Snarska C., Szkolenia pracowników z zakresu elastycznych form pracy. Poradnik dla instytucji szkoleniowych, Wydawnictwo Wyższej Szkoły Ekonomicznej w Białymstoku, Białystok 2007.

Sadowska-Snarska C., Elastyczne formy pracy jako instrument ułatwiajacy godzenie życia zawodowego z rodzinnym, Wydawnictwo Wyższej Szkoły Ekonomicznej w Białymstoku, Białystok 2006.

The website of Eurostat: http://ec.europa.eu/eurostat

The website of the Polish Ministry of Labour and Social Policy: http://www.mpips.gov.pl

The website of OECD: http://www.oecd.org 